\title{
Florida's School Library Programs and Achievements: What Can Be Adopted in the Brazilian Context
}

\author{
Adriana Bogliolo Sirihal Duarte \\ Universidade Federal de Minas Gerais, Brazil \\ Visiting Professor at Florida State University, USA
}

\begin{abstract}
What motivated this research was the Brazilian law promulgated in 2010 stating that in 10 years all Brazilian schools should have school libraries. 24 American school librarians were interviewed with the aim of learning from their professional experience the most important points that could be extended to Brazil via transferability of models of organizing and conducting school libraries. Results were coded and categorized. One of them showed that Florida's programs to promote reading were effective, with the participation of most the librarians interviewed. Librarians demonstrated both their involvement in the book selection committees as their enthusiasm in engaging the kids. Getting children to be long life readers was stated as important for at least half of the interviewees. Since Brazilian libraries are failing in this first aspect of their role, this paper focuses on the importance of forming school librarians themselves as readers, so they can become good reading mediators.
\end{abstract}

Keywords: School Libraries, Brazil, Law, Policies, Reading. Literacy, School Librarians, Media Specialists. Curriculum, Interviews

\section{INTRODUCTION}

In 2010, it was promulgated a Brazilian law that stated that in 10 years all Brazilian schools must have school libraries. Six years later we notice that the National and the State School Parameters say nothing about school libraries and that directors and school teachers know little or nothing about it. They even don't know what a school library is for. Another major problem is that the librarian undergraduate and graduate schools at Brazilian Universities are generalists and almost never include courses that discuss school libraries. So, Brazilian Universities are not educating school librarians to work in all those school libraries that will be needed in the next few years. The overall objective of this research was to find possibilities for development and improvement for the school library curricula and for the Brazilian school libraries. It consisted of three research questions:

- RQ1: What advantages would a Masters' Degree requirement, like in USA, give to Brazilian school librarians to work in school library?

- RQ2: How can Brazil use the American example in school libraries and from their librarians to improve its own school libraries?

- RQ3: How can online courses in Brazil be improved for school librarianship education?

To answer these questions, the plan was to evaluate various requirements and American curriculum frameworks, and to evaluate approaches used in specific courses related to the formation of the school librarian. In addition, American school librarians would be in-depth interviewed. The main purpose of the interview was to investigate the librarians' impressions of their own training and the impact of it in their professional practice.

This work shows partial results of the research, regarding the data collected with the librarians and what contributions they can bring to the formulation of the Brazilian curriculum, so it does not intend to answer the three research questions. In particular, aspects related to the school library program, research and reading in the school library are focused.

SCHOOL LIBRARIES IN BRAZIL 
Brazilian Law No. 12.244/2010 promotes the universalization of libraries in educational institutions over the country and is composed of 4 articles, which can be summarized as follows: the public and private educational institutions of all education systems in the country will have libraries, under the terms of this Law. For the purposes of this Law, a school library is a collection of books, video materials and documents registered in any medium for consultation, research, study or reading. At least one title for each enrolled student will be required in the collection, and it is up to the respective education system to determine the expansion of this collection according to its reality, as well as to disseminate guidelines for the storage, preservation, organization and functioning of school libraries. The country's education systems should make progressive efforts to ensure that the universalization of school libraries, in the terms established in this Law, takes place within a maximum period of ten years, respecting the profession of Librarian. (Law 12.244, 2010)

What pros and cons can be perceived in the analysis of the text of law 12.244? It is certainly positive that this is the first law that guarantees the presence of the school library in all educational establishments in the country, regardless of its level (whether elementary, middle, or high schools ${ }^{1}$, or even at universities) or type (public or private). However, several points are at least questionable:

1) The law establishes a period of ten years for the country's education systems to conform to what has been established, but does not provide for penalties if this does not occur, nor mechanisms to evaluate the implementation of libraries and their quality.

2) The very understanding of what should be a school library in the text of the law is quite narrow. The school library is defined only in terms of collection. Nothing is said about technology, much less about a library program, based on reading, literacy and research activities, collaboration with teaching and curricular activities, among others.

3) The law does not guarantee, at any moment, the hiring of properly qualified librarians to work in school libraries. Its text is very fluid, when the terminology "respected the profession of librarian" is adopted.

This reflects the immaturity policies for school libraries historically existing in Brazil. In summary, it can be said that until now Brazilian efforts have focused only on seeking to promote access to the book, aiming to put the physical material in the reader's hand, without any initiative to mediate the reading process. Thus, the largest Brazilian initiative in terms of school library ever carried out is the so called "Library in the School National Program" (Programa Nacional Biblioteca na Escola - PNBE), which although received this name, has little or none effective relationship with the school library. It is a program that provides for the distribution of books in schools. Created in 1997, its main objective was "to democratize access to Brazilian and foreign literature for children and young adults, as well as to provide research and reference materials to teachers and students" (Paiva, 2012, p.14).

The Diagnostic Evaluation of the PNBE, a research developed in 2005 and published in 2008, demonstrates the lack of knowledge of the government, the school administrators, and the teachers themselves of what school libraries are (or should be). The situation is so chaotic that when visiting the sample schools to make such a diagnosis, the researchers did not specifically search for libraries, but questioned the existence of libraries or reading rooms. According to the evaluation,

As far as library conceptions are concerned, there is usually an emphasis on the physical structure, and a separation between it and projects to encourage reading. When asked about the library ideal that each person interviewed had, especially those who work directly with the reading rooms found, it was observed that no references were made to the role of the library as a promoter of actions aimed at encouraging reading and writing, but only as a physical space for depositing materials for such actions to happen under the guidance of teachers and coordinators, never of those responsible for the space or as the basis of a library program. (Brasil, 2008, p. 124)

\footnotetext{
${ }^{1}$ In Brazil, those would be called fundamental $\left(1^{\text {st }}\right.$ to $9^{\text {th }}$ grade $)$ and secondary or middle $\left(10^{\text {th }}\right.$ to $12^{\text {th }}$ grade $)$ school.
} 
Of the total of 1087 individuals who composed the diagnosis sample, among which teachers, school directors, pedagogues, students, parents, and others, there were counted 5 librarians and 152 people responsible for libraries (without librarian training).

Despite the existence of book distribution policies, the absence of mediation, whether through the school libraries or in any other way, is felt when it is verified that Brazil is not a nation of readers. This is what the research Portraits of Reading in Brazil shows us, in its fourth edition. Its objective is to know the reader behavior, measuring the intensity, form, limitations, motivation, representations and the conditions of reading and access to the book - printed and digital - by the Brazilian population. In this research, a reader is considered anyone who has read, in whole or in part, at least 1 book in the last 3 months. So, non-reader is the one who stated that he / she had not read any book in the last 3 months, even though he / she has read it in the last 12 months. Using these definitions, in 2015, 56\% of Brazilian population was composed by readers, and $44 \%$ by non-readers. But only $26 \%$ of Brazilians answered that they've bought any book in the last 3 months. Among all interviewees, the medium number of books read (in whole or in part) in 2015 was 2.54 . From those, only 1.06 were read from cover to cover. (Failla, 2016)

Castro Filho and Coppola Junior (2012) present data from the 2010 Brazilian School Census, which show that school libraries in that country existed in approximately $30 \%$ of elementary schools and less than $60 \%$ of middle schools:

The School Census, conducted annually by Instituto Nacional de Estudos e Pesquisas Educacionais Anísio Teixeira (INEP) is the most relevant and comprehensive statistical survey on basic education in Brazil (Brasil, 2010, p.1). In the Technical Summary - School Census 2010, the number of fundamental schools in the country with a library (Brasil, 2010, p.33) is indicated in the "Infrastructure" requirement, divided into two groups: 1) Schools of the first grades ( $1^{\text {st }}$ to $5^{\text {th }}$ grade), totaling 42,029 schools (30.4\%); 2) Schools in the final grades (6 $6^{\text {th }}$ to $9^{\text {th }}$ grade), totaling 36,417 schools (58.7\%). This statistical survey is composed of primary, public (federal, state and municipal) and private schools, however there may be differences in the total of "attended schools", due to the incorrect concept of school library applied by the school administration. (Castro Filho \& Coppola Junior, 2012, p. 31).

What this brief review shows is that the current Brazilian situation is that of a country that needs to install school libraries, who does not know their meaning and concept, even does not know what means a library program. Our country currently is incapable of forming readers, as well as it has not even reached the initial stage to be able to offer school libraries where the literacy is given.

\section{Data Collection and Analysis}

\section{METHOD}

This paper presents research results regarding the data collected through in-depth interviews with 24 American school librarians. As the researcher was performing sabbatical at Florida State University, a survey of the Leon County schools was originally conducted. According to publicly released data (http://jobs.teacher.org/school-district/leon-county-schools\#), in 2014 Leon County had 42 school librarians (called media specialists) and 10 library assistants and technicians, for a total of 52 schools (including 38 public schools of which 24 were elementary schools, 8 middle e 6 high schools, and the others classified among private, virtual, university, special schools, etc.).

Eighteen school librarians from Leon County were interviewed (1 from school K-12, 4 from high schools, 5 from middle schools, and 8 from elementary schools). After that, trying to expand the comprehension, 6 school librarians from other counties were also interviewed by skype (2 PreK-12, $1 \mathrm{~K}-$ 5, 1 from high school, 1 from middle school and 1 from elementary school) (See Table 1). The interviews were conducted from November 2016 through March 2017. They were all audio recorded for posterior transcription and coding, and their average duration was 50 minutes, with the longest taking $1 \mathrm{~h} 10 \mathrm{~m}$ and the shortest 35 minutes. 
As far as the designation used to express the facilities in which the librarians work at their schools, there were found: 17 Media Center, 2 Information Resource Center, 1 Learning Resource Center, 1 Learning Commons, 1 Media Resource Center, 1 Knowledge Center, and 1 Library. 
Table 1. Profile of research participants

\begin{tabular}{llll}
\hline Respondent & District & School Type & Library Designation \\
\hline R1 & Leon/FL & K-12 & Media Center \\
R2 & Polk/FL & Elementary & Media Center \\
R3 & Leon/FL & High & Information Resource Center \\
R4 & Leon/FL & High & Information Resource Center \\
R5 & Orange/FL & PreK-12 & Learning Resource Center \\
R6 & Leon/FL & High & Media Center \\
R7 & Leon/FL & Middle & Media Center \\
R8 & Leon/FL & Elementary & Media Center \\
R9 & Leon/FL & Middle & Learning Commons \\
R10 & Leon/FL & High & Media Center \\
R11 & Leon/FL & Elementary & Media Center \\
R23 & Leon/FL & Middle & Media Center \\
R13 & Leon/FL & Elementary & Media Center \\
R14 & Leon/FL & Elementary & Media Center \\
R15 & Leon/FL & Elementary & Media Center \\
R16 & Leon/FL & Elementary & Media Center \\
R17 & Leon/FL & Elementary & Media Center \\
R18 & Leon/FL & Middle & Media Center \\
R19 & Leon/FL & Middle & Media Center \\
R20 & Leon/FL & Elementary & Media Center \\
R21 & 181/IL (Handsale) & K-5 & Media Resource Center \\
R22 & Windermere/FL & PreK-12 & Knowledge Center \\
R23 & Needham/MA & Middle & Library \\
R24 & Boca Raton, FL & High & Media Center \\
\hline
\end{tabular}

About terminology, only one librarian showed concern in being called a librarian rather than a media specialist. According to her,

That's because I think back in the '70s. When libraries became more than books. To make an awareness that libraries had technology, and they had audiovisual, and they have kits, more than just books. They changed the name to media centers, to try to keep up with the times. Now, I think that name does us a disturbance. Because not everyone knows what a media center is, and they don't really understand what a media specialist is. So, when you hear when the general public, the parent hears "your school is cutting media specialist", they might think "well, I know we are in tight budget times, you know, we can't afford having morning news program" or "we can't afford to have the video team" or something like that. But if you say, "Do you realize your school librarian has been cut?" that has a whole other meaning to them. They understand what a school librarian is. I think continuing to call ourselves media specialists and media centers from back in the seventies, because everyone knows now that libraries are more than books, that's understood, but what's not understood is that your school librarian and your school library is being cut, and not being funded. That's what people don't realize. But when they hear your media center is not being funded that doesn't resonate with them. So, AASL, American Association of School Librarians, that's our national group, about 5 years ago, I think, said "we are calling ourselves school librarians", that's the official term. Not everyone hear to that. Because of habit. You know, there were habit to call it media center, there were 
habit in calling them media specialists. (...) And I think also it's important to go back calling us school librarians so that the general public understand what's happening with our field.

The others have demonstrated either to be satisfied or to not care about the denominations used to designate their professions (media specialist) or their places of work. The justifications were several, but always related to the fact that "we are more than a library", either because currently the collection includes things that go beyond books, or because those facilities are no longer the space that values silence and concentration, as shown in the following statements:

We are not libraries, libraries are quietly study areas where people read either to seek information or to be entertained. Media centers, the movement, I would say that was probably around the 80s, Media Center was a multimedia emphasis because we had film strips, listening stations, audio books, visual, audiovisual content, we had CDs, then we had CD-ROMs, then we went to DVDs, and interactive DVDs. So, I do believe here, I encourage kids not to call it a library, it is a media center. In a library, you have to be silent. In a media center, you work together and collaborate. I mean, it's a philosophy that's different. But I think we are ready to, I don't want to go back to the word library, to me that's very closing, very narrowing, but I would move forward to an Information Resource Center.

We just got started with the name media center. It's just kind of float. I know some places they called theirs the IRC, so it's the Information of Resource Center and they just refer to it as the IRC. Well, part of that in going with being called a media specialist instead of a librarian even though, I don't care, they can call me whatever they want. Because now we deal so much in more than just books, a lot of my time is being dealing with this kind of thing, troubleshooting things, and helping kids, like we had one of the teachers, we just finished up a big project where they came in and they made movie trailers...

After collecting and transcribing all data, they were coded and categorized for further analysis. The free coding method was used with constant comparison, that is, with each new code that emerged, all passages from already coded interviews were revised, in order to review the consistency of the coding and the need for readjustment. Finally, the codes were categorized, generating the following frame of analysis.

Table 2. Codes and Categories for Data Analysis

\begin{tabular}{|c|c|c|}
\hline Category & Code & Explanation \\
\hline \multirow{6}{*}{$\begin{array}{l}\text { Background \& } \\
\text { Foreground }\end{array}$} & Continuing education & $\begin{array}{l}\text { Workshops, events, courses, etc., taken or } \\
\text { done by the librarian }\end{array}$ \\
\hline & Decision to become a librarian & $\begin{array}{l}\text { When, how, and/or why the person decided } \\
\text { to become a librarian }\end{array}$ \\
\hline & Formation & $\begin{array}{l}\text { Courses, faculties, colleges, master programs } \\
\text { taken by the librarian }\end{array}$ \\
\hline & Job experience & $\begin{array}{l}\text { Experience working as a librarian (hol long } \\
\text { has been working, places where have } \\
\text { worked, etc.) }\end{array}$ \\
\hline & Prior Jobs & $\begin{array}{l}\text { Places where the librarian worked before, in } \\
\text { other professions }\end{array}$ \\
\hline & Teaching experience & $\begin{array}{l}\text { Indication about the librarian having (or not) } \\
\text { previous experience as a teacher }\end{array}$ \\
\hline \multirow[t]{2}{*}{ Master Program } & Courses & $\begin{array}{l}\text { Courses, subjects, or experiences that were } \\
\text { mentioned as important }\end{array}$ \\
\hline & Internship & Importance of internship during formation \\
\hline
\end{tabular}




\begin{tabular}{|c|c|c|}
\hline Category & Code & Explanation \\
\hline & Knowledge from other sources & $\begin{array}{l}\text { Knowledge or content that was not acquired } \\
\text { in the Master Program, that maybe could be } \\
\text { included in the courses }\end{array}$ \\
\hline & Online Master & $\begin{array}{l}\text { Impressions about the modality - online or } \\
\text { face-to-face - of the classes }\end{array}$ \\
\hline \multirow{15}{*}{ Job } & Assistant & $\begin{array}{l}\text { Indication of presence of aides: assistants, } \\
\text { volunteers, students, etc. }\end{array}$ \\
\hline & $\begin{array}{l}\text { Being a teacher versus being a } \\
\text { librarian }\end{array}$ & Comparison between the two jobs \\
\hline & Budget & Explanation about fund raising and budgeting \\
\hline & Cataloging & $\begin{array}{l}\text { How to catalog, software used, system used, } \\
\text { genrefing, etc. }\end{array}$ \\
\hline & Circulation & Circulation numbers \\
\hline & Collaboration & $\begin{array}{l}\text { Evidence of collaborative work with teachers } \\
\text { in distinct levels }\end{array}$ \\
\hline & Collection & $\begin{array}{l}\text { How to make a purchase, criteria for } \\
\text { selecting books, fiction and nonfiction } \\
\text { sections }\end{array}$ \\
\hline & E-books & $\begin{array}{l}\text { Evidence of e-books in the collection and } \\
\text { information about their use }\end{array}$ \\
\hline & ExC3EL & $\begin{array}{l}\text { Evidence of knowledge or use of ExC3EL } \\
\text { Rubric or application for Florida Power's } \\
\text { Library Award }\end{array}$ \\
\hline & Need for advocating & $\begin{array}{l}\text { Evidence of librarian advocating for her/his } \\
\text { profession of for the work done in the library }\end{array}$ \\
\hline & No routine & Indication that there's no routine in the job \\
\hline & Operating times & Library schedule or operating times \\
\hline & Research Model & $\begin{array}{l}\text { Use of FINDS or BIG6 or any research } \\
\text { model }\end{array}$ \\
\hline & Tasks & $\begin{array}{l}\text { Things that the librarian do at the school } \\
\text { library }\end{array}$ \\
\hline & Teaching role & $\begin{array}{l}\text { Instructional role of the librarian, evidence of } \\
\text { teaching eventual or scheduled classes }\end{array}$ \\
\hline \multirow{5}{*}{ School Library } & Facility name & $\begin{array}{l}\text { Why using any specific name and the opinion } \\
\text { of the librarian about it }\end{array}$ \\
\hline & Librarian per school & $\begin{array}{l}\text { Indication of presence (or not) of a librarian } \\
\text { in all schools of the county }\end{array}$ \\
\hline & Place for information & $\begin{array}{l}\text { How do the librarian conceive a school } \\
\text { library }\end{array}$ \\
\hline & Place for the kids & $\begin{array}{l}\text { How do the librarian conceive a school } \\
\text { library }\end{array}$ \\
\hline & Social context & $\begin{array}{l}\text { Influence of social and economic context at } \\
\text { school libraries and students' lives }\end{array}$ \\
\hline
\end{tabular}




\begin{tabular}{lll}
\hline Category & Code & Explanation \\
\hline Type of school & $\begin{array}{l}\text { Classification when indicated by the } \\
\text { respondent (elementary, middle, high, } \\
\text { private, community, etc.) }\end{array}$ \\
\cline { 2 - 3 } AR & $\begin{array}{l}\text { Librarian impressions about the Accelerator } \\
\text { Reading Program; evidence of participation, } \\
\text { etc. } \\
\text { Importance of librarian and teachers to be } \\
\text { Leading }\end{array}$ & $\begin{array}{l}\text { good readers } \\
\text { Student participation and librarian as part of } \\
\text { committee }\end{array}$ \\
& Reading Award Programs & $\begin{array}{l}\text { Getting the students to read } \\
\text { Impact of reading \& library in kids results }\end{array}$ \\
\hline
\end{tabular}

As can be seen, there are a lot of data to be processed, and its analysis can promote numerous and diversified works. In this paper, the focus is on the following aspects: the importance of the reader's formation in the school library. To do so, the coded data marked with shading in table 2 was used. The results will be presented making use of, whenever possible, excerpts from the interviews to corroborate the analyzes. Respondents will not be identified.

\section{RESULTS}

One of the research points of interest was what courses should be included in a Brazilian library curriculum in order to better contemplate the formation of school librarians. To answer this question, my strategy was to ask American school librarians what courses they had taken during their training that they considered important or useful to them in their professional lives.

According to the 6A-4.0251 Specialization Requirements for Certification in Educational Media Specialist (Grades PK-12) - Specialty Class (2000), the specialization requirements for certification in educational media specialist are

(1) Plan One. A bachelor's or higher degree with an undergraduate or graduate major in educational media or library science, or

(2) Plan Two. A bachelor's or higher degree with thirty (30) semester hours in educational media or library science to include credit in the areas specified below:

(a) Management of library media programs;

(b) Collection development. Courses in this area include: evaluation, selection, and maintenance of library media resources in print and nonprint formats;

(c) Library media resources. Courses in this area include: literature in both print and nonprint formats for both children and adolescents;

(d) Reference sources and services. Courses in this area include: print and electronic resources and techniques for providing information services;

(e) Organization of collections. Courses in this area include: classification and cataloging principles and techniques; and,

(f) Design and production of educational media.

Since the sample of the research was composed mostly by Floridian librarians, I was expecting to have one of the six areas specified by the rule as the answer to the question. Without a doubt, the most common answer revolved around the theme of reading, being included in the area (c) literature for children and adolescents. This was unexpected for me, as a Brazilian librarian professor, because in the curriculum offered at my home institution, the only discipline related to reading is optional, being attended only by those who have an interest, it is not compulsory for curricular integration, and in its programmatic content, the students read at most four literary titles. The interviewees showed that their 
reading course was chosen according to the type of school library they were interested to work with elementary, middle, or high school libraries - so that the reading indications reflect the appropriate age grades, from small children to young adults. They all talked about having extensive reading lists, fruitful debates about books read, discussions about authors, readings of reviews, etc.

Those were classes where you read a lot of children's literature, from the perspective of meeting information needs of children and young adults so... how fantasy books tapped to the children's imagination, or fulfill a need that they have for information, how the different genres, how nonfiction is read, you know those kinds of things. So, fulfilling the needs of child through books or... (...) At the time, mostly we read books and talked about how they help kids with their needs through literature. Those I think that were important for a school librarian because as someone who had not taught, I knew some authors, I knew some book titles but not every, I mean that's really where I learned about the authors that were out there, the book titles, genres...

Like, they would give us, I'm trying to remember...I think we were giving lists of titles of novels like the main authors for the age approach and recommended readings and we had to just read, read so just that we were familiar with the different authors for kids, to know who writes those types of books.

At different points in the interview, the respondents always spontaneously mentioned (they were never asked about it) reading programs applied by their district or the state school librarians' association (mostly FAME - Florida Association for Media in Education), as well as the way they applied them in their schools. The Accelerated Reader (AR), the Sunshine State Young Readers Award (SSYRA), and the Florida Teens Read (FTR) were mentioned.

Accelerated Reader (AR) is a software designed to facilitate student reading growth through practice in an educational setting. It has been purchased by many school districts and used in both elementary and secondary schools to encourage and measure the frequency and accuracy with which students read. Its application involves the assessment of a student's reading level through a computer adaptive test. Several studies have been reported on the effectiveness of using AR in the classroom (Krashen, 2002, 2003; Johnson \& Howard, 2003; Pavonetti, Brimmer, \& Cipielewski, 2003; Mallette, Henk, \& Melnick, 2004; Thompson, Madhuri, \& Taylor, 2008), educators have argued that its use does not teach reading for comprehension; but this discussion is not the focus of this work. The AR was not even part of the interview script, but it was mentioned by several interviewees as being, according to them, mandatory in elementary education in some Florida counties. Thus, librarians are forced to use it and eventually mentioned it among the activities of their library routine. Some have expressed their displeasure emphasizing that the AR requirement restricts the library's collection only to materials that are part of the program as well as restricts children's choice to reading only what is appropriate to the level in which they are. Others, on the other hand, demonstrated enthusiasm for the program as a way to encourage reading, describing how they use it to capture students' interest, and engaging them in reading activities.

It's a program that is computer based, and the books are coded, and they read a book and they take a comprehension quiz on the book when they get finished. They get points for this, and that's really big in our school. So, consequently, our library is very busy, because the kids want to get the points from reading the books and taking the quizzes.

... and, of course, our school AR is big too. They have awards. Our school is being Knight. So, if they reach 500 AR points awards they get knighted, and so every nine weeks I put a list and tell them how many points they have and what point clubs and what awards they get for those, and the principal dresses like a queen, and knights them, and they go on the stage. None of it cost a lot of money, but it gives them recognition, which they like, so...

Unlike the AR, which has been imposed by some districts to be applied in school libraries (at least at elementary levels), the FTR and SSYRA are award-winning programs to which the participation is voluntary. There was also no question in the interview script about those, they were spontaneously mentioned by librarians in two different contexts - when they wanted to tell that they were part of the reading committees that selected the books that would be considered for awards in the following year or 
when they wanted to publicize their students' participation reading the award books and voting for the winners.

Basically, what differentiates FTR from SSYRA is the level or grades to which they are designed: the former is a

student-choice reading award program to determine which YA book wins the annual award as the favorite of teens in Florida. The reading list is comprised of fifteen titles that have been chosen by a committee of twelve school librarians specifically to engage high school students (grades 9 through 12) in reading and reflect their interests as well as represent a variety of genres, formats, reading levels, viewpoints, and ethnic and cultural perspectives (FAME, 2017a).

The last is a "statewide reading motivational program for students in grades 3 through 8, sponsored by the Florida Department of Education (DOE) and Florida Association for Media in Education (FAME)" with the purpose to

encourage students to read independently for pleasure and to read books that are on, above, and below their reading level in order to improve their reading fluency. Sunshine State books are selected for their wide appeal, literary value, varied genres, curriculum connections, and/or multicultural representation. The SSYRA committee is comprised of 20 qualified school librarians located throughout the state of Florida, subdivided into two committees- grades 3-5 and grades 6-8 (FAME, 2017b).

In both cases, once the committee chooses the list of books for that year, the student who has read at least three of the selected books is eligible to vote, for the period stipulated for it, in the book he / she liked best. The author of the most voted book receives the award at the FAME annual congress.

During the interviews, the librarians who participated in the committee claimed as advantages of their participation, besides the possibility to read books and debate them with their students, the fact that the publishers send them these books to be considered for the lists of the following year free of charge and, after doing the reading and selection work, they can incorporate the books into the library collection of their schools at no cost.

I have a small group of students, I explained to all my 9th graders, about the committee, the Teens Read Committee, so I have a display, the display out there that says: "read with me". Those are all the books that we are considering and we are going to tell them "these are book that we are considering", and I want you guys to give me feedback and put some bookmarks in there, or write a review. (...) I have a tea and talk, or a teen's read tea, we've had two so far, I will show you the pictures.

And also, I am extremely fortunately, through FAME, being on the Florida Teens Read and the Sunshine State, in such as these read committees, I get the books from the publishers. So, that we can read them to consider them for those lists. So, our school is very fortunate in that since once I've read them and gone through then I can put those on to our collection.

They also shared the strategies they use to promote reading the books and the students' participation in the program: they distribute prizes ranging from stickers, pendants to be hung on chains, they put posters telling how many books each child has read, with their names and pictures, they do parties on voting day, inviting authors to talk with students (even via Skype).

Yes. If they read at least three, they get to vote. I had a big voting party last year, we had a ton of kids and four of the authors of the books last year, we Skyped with them. And it's funny because I wasn't sure I would get anybody so I send it out an email to about 8 just to see what would be possible to Skype in a certain day, blah blah blah, for about 20 minutes or whatever, and then four of them said yes, and I was like "oh! oh!". But the principal gave us permission to just do it during the whole lunch hour, all three lunches, because our kids go in sections to lunch during third period and so he gave permission that if the kids wanted to, they could stay and miss their 3rd period class, so that they could hear all four of the authors, and most of the kids did that, and we had a ton. I don't remember, the whole middle area was just packed, and we fed them lunch, our parent organization paid for them to get sandwiches, we made cupcakes and 
had drinks. So, they had a big lunch, and then Skype with the authors, and they vote. They vote actually as they came in, they got their ballot, they voted, they put it in, got lunch, set down and we got Skype. That was fun. I need to get on a stick about that and see if I can round up some this year. Maybe not sound out so many this time. So, I don't get caught with that again.

The Sunshine State, yes. When I first got here, in the first couple of years, nobody seemed to even know about them, I don't know how much participation they were doing in the elementary school, but especially since I got on the committee, it's like pushing it and pushing it and pushing it. Now, I would say more of our county schools are participating more like, I finally got the other middle schools onboard but come on it's easy, I mean, you just, whatever. They are starting to get a little bit better. Our kids are maniac. (laughs) Just to give you an example, I'll show you over there, that window over there that has a big sun on it, the Sunshine State books, that's where we keep them all, and I've bought like 10, basically, of each title, and there's 15 titles. So, I have basically a hundred and fifty books over there, I see right now there's probably about six or seven, they are all out. They're all checked out.

This Sunshine State books, that's really big at my school, we have a club and they, the kids read the books, five of the books, and then they test on the books, and they get a charm for the books, and they get a t-shirt when they get to participate in the district contest for it. So, it really promotes, it really gets them excited about it, because they like, they work for, I will show you the charms. They work for the charms, their names on the Sunshine Florida State, and they get a neckless, for all the books that they have, so, that's one way...

Finally, as the following selected statements show, in addition to mentioning the reading programs, during the interviews the school librarians emphasized the influence of reading on students' performance in school achievement tests, as well as the importance of the school librarian being a reader, to be able to carry out well his / her role as mediator.

Do you know about the grading systems, where they give a school a grade based on the student scores on the Florida standards assessment? Our school always has scored an A since they came up with that system, and I think a big part of it is because of the amount of books that the kids read on their own.

I think something that's underrated in education all together, not just librarians but teachers too, but specially librarians, you have got to read the literature. If you are going to work with children and recommend the books, you have got to read the books.

Those books deserve to be read too but I don't think you can be a good librarian and help your children become readers if you are not reading as well. And I think that it's just a shame when I talk to librarians and I say "have you read?" and they say "no, I haven't read that" but they haven't really read anything, do you know? I think that's a shame. Makerspaces are hot and that's fine, put out the legos, let's the kids build robots, it's fine. But that can't be all we are doing. Because who else is putting books in kids' hands? Well, it's our job!

The last question in the interview was a question for the respondent to express freely by telling what she or he considered most important in her or his school library. There were basically three groups of responses: the first group consisted of librarians who considered that the school library should be the "place for information" or the "information hub" of the school, serving as the first place where anyone would search for any kind of information. And that even if the library itself was not capable of giving the requested information, it would be able to act as a mediator, directing the user to the correct place where to find the information. The second group was composed of librarians who mentioned that the library was the "children's place". For them, above all, it should be a place where children would feel welcome, comfortable, a place where there would be sharing and collaboration, the opposite of a place of order and silence. Finally, the third group considered that the most important thing was that the library was the "place of literature and literacy". The place where children learned to become lifelong readers and lifelong learners, the place to let them keep their enthusiasm and pleasure in reading.

\section{CONCLUSION}


Among the six topics required for the certification of the Florida media specialist listed above, the most mentioned in the interviews conducted is just the least contemplated in the curricula that form the Brazilian librarians. One of the objectives that led to the conduction of this research was to verify what contributions the American experience could give to the Brazilian curricular reformulation. Currently, the formation of the Brazilian librarian is generalist, and is not able to prepare the professional to work specifically in the school library environment. It fails, precisely, by not preparing the librarians for their instructional role and, as discussed throughout this work, by not involving them with literature. Thus, the Brazilian school librarians know little about the appropriate authors for the children and adolescents reading. This is evidently reflected in a weak capacity to getting the kids to be readers.

Brazil is offering, politically, an opportunity for growth to the school environment by creating a legislation that regulates the existence of school libraries in all educational establishments. For this to become an effective action, the path is long. As already discussed, making available only the collection will not lead to any result. Offering libraries must be more than that. Through this research, the American experience wisely showed us that the initial path is that of reading. One cannot talk about a robust library program, with literacy, teacher-librarian collaboration, and so on, in schools where there are no readers. Children who cannot read are unable to judge the value of information.

As our courses in the Brazilian bachelors for librarians offer with quality the other items proposed in the Florida requirements for certification in educational media specialist, in particular with regard to the topics collection development, reference sources and services, and organization of collection, it is suggested the investment in teaching the themes related to reading, literature, literacy, and the instructional role of the librarian for those individuals wishing to work in the field of school librarianship.

\section{REFERENCES}

6A-4.0251 Specialization requirements for certification in educational media specialist (Grades PK-12) - Specialty class (2000). Retrieved May 2, 2017 from https://www.flrules.org/gateway/RuleNo.asp?ID=6A-4.0251

Brazil. Ministério da Educação. (2008). Programa Nacional Biblioteca da Escola (PNBE): leitura e bibliotecas nas escolas públicas brasileiras. Brasília, Brazil: Ministério da Educação. Retrieved May 02, 2017 from http://portal.mec.gov.br/seb/arquivos/pdf/Avalmat/livro_mec_final_baixa.pdf

Brazil. Ministério da Educação. (2010). Resumo Técnico - Censo Escolar 2010. Brasília, Brazil: INEP. Retrieved May 2, 2017 from http://portal.mec.gov.br/component/docman/?task=doc_download\&gid=7277\&Itemid= Castro Filho, C. M., \& Coppola Junior, C. (2012). School library and the law 12,244, 2010: ways to implementation. Biblioteca Escolar em Revista, 1 (1), 30-41.

Failla, Z. (org.) (2016). Retratos da Leitura no Brasil 4. Rio de Janeiro, Brazil: Sextante.

Retrieved May 2, 2017 from

http://prolivro.org.br/home/images/2016/RetratosDaLeitura2016_LIVRO_EM_PDF_FINAL_COM_CA PA.pdf

FAME (2017a). Florida teens read. Retrieved May 1, 2017 from

http://http://www.floridamediaed.org/florida-teens-read.html

FAME (2017b) Sunshine State Young Readers Award. Retrieved May 1, 2017 from

http://www.floridamediaed.org/ssyra.html

Johnson, R. A. \& Howard, C. A. (2003). The effects of the accelerated reader program on the reading comprehension of pupils in grades three, four, and five. The Reading Matrix. 3(3), 87-96.

Krashen, S. (2002) Accelerated reader: Does it work? If so, why? School Libraries in Canada. 22(2), 24 $-26$.

Krashen, S. (2003), The (lack of) experimental evidence supporting the use of Accelerated Reader. Journal of Children's Literature. 29(2): 9, 16-30. 
Law 12.244 (2010). Provides for the universalization of libraries in Brazilian educational institutions. Retrieved May 2, 2017 from http://www.planalto.gov.br/ccivil_03/_ato2007-2010/2010/lei/112244.htm Mallette, M. H., Henk, W. A., \& Melnick, S. A. (2004). The influence of Accelerated Reader on the affective literacy orientations of intermediate grade students. Journal of Literacy Research. 36 (1), 73 84.

Paiva, Aparecida (Org.). (2012). Literatura fora da caixa: o PNBE na escola, distribuição, circulação e leitura. São Paulo, Brazil: Ed. Unesp.

Pavonetti, L. M., Brimmer, K. M., and Cipielewski, J. F. (2003). Accelerated Reader: What are the lasting effects on the reading habits of middle school students exposed to Accelerated Reader in elementary grades? Journal of Adolescent \& Adult Literacy. 46(4), 300-311.

Schmidt, R. (2008). Really reading: What does Accelerated Reader teach adults and children? Language Arts, 85(3), 202-211.

Thompson, G., Madhuri, M., \& Taylor, D. (2008). How the Accelerated Reader Program can become counterproductive for high school students. Journal of Adolescent \& Adult Literacy, 51(7), 550-560. 